\title{
Conceptual study of transesterification of vegetable oils in the continuous- stirred-tank reactor at unsteady-state and isothermal conditions
}

\author{
Fadzil Noor Gonawan*, Azlina Harun Kamaruddin \\ School of Chemical Engineering, Engineering Campus, Universiti Sains Malaysia, \\ 14300 Seri Ampangan, Nibong Tebal, Pulau Pinang.
}

\begin{abstract}
The continuous-stirred-tank reactor (CSTR) is favorable for bi-phasic enzymatic reaction due to ease of operation, cost-effective and low downtime. The lack of study on the enzymatic reaction in the CSTR has disfavor this type of reactor compared to batch and packed bed. The purpose of this study is to prove the feasibility of enzyme-catalyzed production of biodiesel in the CSTR using the mathematical model and simulation. The model incorporated the effect of the kinetic, thermal, and operating parameters. Then, it was solved using Polymath 6.1 software. Then, suitable enzyme characteristics and operating conditions are suggested. A high conversion could be achieved by choosing an appropriate lipase and operating conditions. The lipase with $K_{I}>100 \mathrm{~mol} / \mathrm{L}, K_{m}<0.15$ $\mathrm{mol} / \mathrm{L}$, and $\Delta G_{\text {inac }}>120 \mathrm{~kJ} / \mathrm{mol}$ were selected as they are resistant to methanol inhibition, showing a high affinity for the oil substrate and thermally stable. For a thermally sensitive enzyme, the operating temperature should remain constant at its optimal level to avoid over denaturation. In addition, the residence time for the triglycerides is prolonged (>20 hr) whereas for the methanol is shortened since it can increase the conversion. This can be achieved by reducing the volumetric flow rate of the triglycerides over the methanol. However, it must not be too low to prevent lower productivity. This article highlights that the production of biodiesel using enzyme-catalyzed reaction can be feasible if an appropriate lipase and operating conditions are employed.
\end{abstract}

Keywords: Enzymatic, CSTR, Transesterification, Biodiesel, Lipase.

*For correspondence: chfadzil@usm.my

Received: 14 Sept 2020 Accepted: 02 Apr 2021

(C) Copyright Gonawan et al. This article is distributed under the terms of the Creative Commons Attribution License, which permits unrestricted use and redistribution provided that the original author and source are credited.

\section{Introduction}

The approach of biodiesel synthesis from vegetable oils via transesterification with alcohol imparted issues on the sustainability of the process especially its impacts on the environment and net production cost. The synthesis can either be readily carried out using acid, base or enzyme catalyst. The pros and cons of each method have been reviewed elsewhere [1]. Generally, the enzyme-catalyzed process is more sustainable than other approaches (Figure 1). This is because it requires mild reaction temperature, without side reaction, leads to simple downstream purification and recovery of other highvalued products. Nevertheless, the enzymatic approach possesses a high risk from the perspective of an investor or process engineer. The concerning issues are on the cost, reusability and stability of the catalyst. Due to this reason, a chemical catalyst has been used despite corrosion issues and the high volume of wastewater generated.

An enzyme in its native form exhibits the highest activity. However, they are prone to deactivation and 
recovery which are impossible with nano size molecules. Currently, various methods are available to immobilize enzymes on organic and inorganic polymeric supports to ease the recovery process [2,3]. The reusability and the stability of the enzyme have been significantly improved [4]. In addition, if the enzyme is produced and prepared onsite it can further reduce the cost of the entire process.<smiles>[R]C(=O)OCC(COC([R])=O)OC([R])=O</smiles>

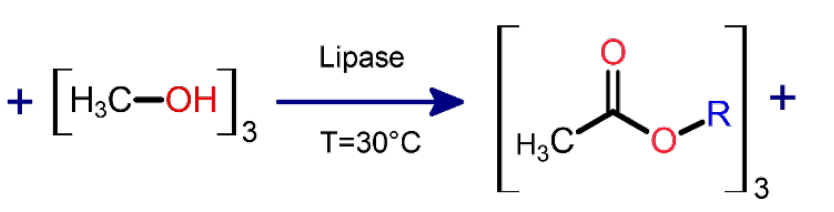<smiles>OCC(O)CO</smiles>

Figure 1. Lipase-catalyzed synthesis of fatty acid methyl ester or biodiesel from triglycerides.

The remaining issue is on the biocatalytic reaction occurring in the reactor that is apparently not well understood. An enzyme lipase for instance is prone to inhibition by alkyl donor of methanol for biodiesel synthesis and sensitive to the change of temperature $[5,6]$. The activity of lipase might reduce in the presence of methanol which act as inhibitor and permanently deactivates or denatures when exposed to high temperature. Another alkyl donor has been proposed to eliminate the inhibitor such as the introduction of methyl acetate and ethanol $[7,8]$. Due to the exceptionally high cost of solvents, methanol is more preferable compared to other solvents. Alternatively, the intermittent feed of methanol was proposed such that the inhibitory effect could be reduced [9].

There are various options available to conduct biocatalytic reaction for biodiesel production such as batch, continuous-stirred-tank (CSTR) and packed-bed (PBR) reactors [10-13]. Until today, batch and PBR have been the most applied reactors for bench-scale studies due to their ease of operation in a small scale. Meanwhile, the CSTR is completely disfavoured. Technically, several criteria should be considered before choosing the appropriate reactor for any chemical reaction. The comparison between these reactors based on various criteria is listed in Table 1. Based on the comparison, CSTR is a good option for the mass production of biodiesel with minimum drawbacks compared to the PBR. For instance, a high initial concentration of alcohol substrate fed into the PBR might increase the risk of lipase inhibition. Meanwhile, an uneven rate of reaction along the PBR causes the biocatalyst close to the reactor inlet denatured or deactivated faster compared to the one at the reactor outlet. Besides, the pressure drop and surface contact are the main issues especially when two-phase liquid exists due to a large density difference between the alcohol and oil.

Table 1. Brief comparison between batch, stirred-tank, and packed-bed reactor for a continuous enzyme-catalyzed reaction.

\begin{tabular}{llll}
\hline Criterion & Batch & CSTR & Packed Bed \\
\hline Mode of operation & Batch & Continuous & Continuous \\
Reaction Phase & Single/dual & Single/dual & Single \\
Initial Substrate concentration & High & Low & High \\
Exposure to inhibitor & High & Low & Low \\
Downtime & High & Negligible & Negligible \\
Reverse reaction & Most affected & Less affected & Less affected \\
Dispersion of biocatalyst & Good & Good & Not applicable \\
Pressure drop & Not applicable & Not applicable & High \\
Feed velocity & Not applicable & Flexible & Limited by pressure drop \\
Rate of reaction & Homogeneous & Homogeneous & Gradient \\
\hline
\end{tabular}


The transesterification of triglycerides and methanol by enzyme-catalyzed reaction can be done in a CSTR since it allows good dispersion and wide range of feed flow rates. It is also possible to carry out the biphasic reaction with an additional small amount of water to enhance the catalytic activity. However, various reactions and operating parameters could affect the output parameters such as conversion, degree of inhibition, catalyst activity, the rate of reaction and others [14-16]. The combined effects of multiple input parameters make the analysis more complicated. For example, a decreased conversion could be due to the inhibition, enzyme deactivation, shorter residence time and reaction temperature. In order to achieve a sustainable process, the CSTR must exhibit a constant conversion, prolong the half-life of the biocatalyst and operate at lower reaction temperatures.

In the present work, a conceptual study of an unsteady-state and isothermal enzymatic reaction of biodiesel synthesis is carried out in a CSTR. It used to prove the feasibility and sustainability of the process. Kinetics and operating parameters were varied to simulate the actual case scenario and the process outcomes. Subsequently, appropriate enzyme characteristics and operating conditions were suggested.

\section{Model development}

\section{Unsteady-state mols balance in the CSTR}

Triglycerides and methanol are the key substrates of biodiesel synthesis. Ideally, these two substrates are fed separately into the reactor to provide better control on its concentration. The mols balance of any compound in the CSTR is given by;

$$
\left[\begin{array}{c}
\text { Rate } \\
\text { accumulation } \\
\text { of comp. } i
\end{array}\right]=\left[\begin{array}{c}
\text { inlet molar } \\
\text { flow rate } \\
\text { of comp. } i
\end{array}\right]-\left[\begin{array}{c}
\text { Outlet molar } \\
\text { flow rate } \\
\text { of comp. } i
\end{array}\right]+\left[\begin{array}{c}
\text { Rate of } \\
\text { generation } \\
\text { of comp. } i
\end{array}\right]
$$

It can be written in an ordinary differential equation as;

$$
\frac{d N_{i}}{d t}=F_{i, o}-F_{i}+r_{i} V
$$

Where, $F_{i}$ is the molar flow rate of the species $i(\mathrm{~mol} / \mathrm{h}), r_{i}$ is the reaction rate of species $i(\mathrm{~mol} / \mathrm{L} . \mathrm{h}), V$ is the volume of the CSTR and $N_{i}$ is the mole of species $i$. The molar flow rate is also defined as the species molar concentration $\left(C_{i}\right)$ multiplied by the fluid volumetric flow rate $\left(v_{o}\right)$ which is given as

$$
F_{i}=v_{o} C_{i}
$$

The concentration of each compound at time, $t$ can be solved through the derivation of Equation 2 to get the following equations;

$$
\begin{aligned}
& \frac{d C_{\text {oil }}}{d t}=\left(v_{\text {oil }, o} C_{\text {oil }, o}-v_{\text {out }} C_{\text {oil }}\right) \frac{1}{V}+r_{\text {oil }} \\
& \frac{d C_{m e t}}{d t}=\left(v_{\text {met }, o} C_{\text {met }, o}-v_{\text {out }} C_{\text {met }}\right) \frac{1}{V}+r_{\text {met }} \\
& \frac{d C_{\text {bio }}}{d t}=C_{\text {bio }} \frac{v_{\text {out }}}{V}+r_{\text {bio }} \\
& \frac{d C_{\text {gly }}}{d t}=C_{\text {gly }} \frac{v_{\text {out }}}{V}+r_{\text {gly }}
\end{aligned}
$$

Where, the total outlet volumetric flow rate $\left(v_{\text {out }}\right)$ is equivalent to the total inlet volumetric flow rate of triglyceride oil and methanol which feed in separately. This setup is adequate to control the feed ratio of the substrate. Hence $v_{\text {out }}$ is given as; 


$$
v_{\text {out }}=v_{\text {oil }, o}+v_{m e t, o}
$$

Whereas, the rate of formation and consumption of the products $\left(r_{\text {bio }}\right.$ and $\left.r_{\text {rgly }}\right)$ and substrates $\left(r_{\text {oil }}\right.$ and $r_{m e t}$ ) are given in the following subsection. The Equation 4 to Equation 7 will be solved simultaneously using Polymath 6.1 software.

There is a various factor which could lead to the unsteady-state behavior in the CSTR, the most notable is due to the accumulation of excess mass or energy within the reactor system. However, in the present work, the unsteady-state behavior is due to the accumulation of component i. Based on Equation 2 the accumulation of the substrate may occur due to the rate consumption of the substrate is less than the feeding rate or vice-versa. This is because the enzymatic rate reaction could vary depending on the real-time concentration of the substrates and the inhibitors. The reaction environment $(\mathrm{pH}$, temperature) and operating conditions (agitation rate, type of solvent) can be the contributing factors as well.

\section{Rate of enzymatic reaction}

The general formula of an enzyme-catalyzed reaction between triglycerides and methanol is shown in Figure 1. The reaction is best described by ping-pong bi-bi mechanism of bi substrate reaction with the following rate of reaction;

$$
r_{\text {oil }}=-\frac{E_{o} k_{c a t} C_{o i l} C_{m e t}}{K_{M, o i l} C_{o i l}+K_{M, m e t} C_{m e t}+C_{o i l} C_{m e t}}
$$

It has been reported that methanol is known to be the inhibitor during the reaction. Hence, the rate consumption of the substrate is given as;

$$
r_{\text {oil }}=-\frac{E_{o} k_{c a t} C_{\text {oil }} C_{m e t}}{K_{M, m e t} C_{o i l}+K_{M, o i l} C_{m e t}\left(1+\frac{C_{m e t}}{K_{I, m e t}}\right)+C_{o i l} C_{m e t}}
$$

Whereas, the rate consumption of the substrates and rate formation of the products can be correlated as in the following stoichiometric ratio;

$$
\frac{r_{o i l}}{-1}=\frac{r_{m e t}}{-3}=\frac{r_{\text {bio }}}{3}=\frac{r_{g l y}}{1}
$$

\section{Effect of temperature on the enzyme}

Most of the enzymatic reactions show a gradual increase in conversion when the temperature is raised to their optimum level before it declines due to the denaturation. The mechanism was described in a two-step process by Daniel and co-workers [17]. The following equation is used to estimate the reaction rate velocity.

$$
V_{\text {max }}=\frac{k_{c a t} E_{o} e^{-\frac{k_{\text {inac }} K_{e q} t}{1+K_{e q}}}}{1+K_{e q}}
$$

Where the values of the catalytic turnover, inactivation constant and equilibrium constant are affected by the temperature according to the following equations [17]; 


$$
\begin{aligned}
k_{\text {cat }} & =\frac{k_{B} T}{h} e^{-\left(\frac{\Delta G_{\text {cat }}^{\ddagger}}{R T}\right)} \\
k_{\text {inact }} & =\frac{k_{B} T}{h} e^{-\left(\frac{\Delta G_{\text {inac }}^{\ddagger}}{R T}\right)} \\
K_{e q} & =e^{\frac{\Delta H_{e q}}{R}\left(\frac{1}{T_{e q}}-\frac{1}{T}\right)}
\end{aligned}
$$

Meanwhile, the effect of temperature on the Michaelis and inhibition constants are given as;

$$
\begin{gathered}
K_{m}=K_{m, o} \exp ^{\left(-\frac{\Delta H_{m}}{R T}\right)} \\
K_{I, \text { met }}=K_{I, o} \exp ^{\left(-\frac{\Delta H_{I}}{R T}\right)}
\end{gathered}
$$

\section{Scope of the study}

The simulation study was carried out for lipase-catalyzed transesterification of triglycerides with alcohol. It was assumed that the reaction was carried out in an isothermal condition and the loss of lipase activity was only due to deactivation or denaturation. A new biocatalyst was not added to the reactor throughout the reaction period and it was also assumed that the biocatalyst exiting the reactor was quickly recycled by appropriate means (i.e., decantation or physical filtration), hence the lipase concentration in the reactor remains constant.

The enzyme kinetic data from the literature shown in Table 2 were used as a basis for the simulation. The values reported seem inconsistent, however, this finding is understandable since it highly depends on the reaction and operating conditions during evaluation. The same type of enzyme does not necessarily give the same kinetic values; therefore, every batch of enzyme exhibits different performance. Even though they are having a similar unit activity, their response towards the change of temperature might be different. A similar phenomenon occurs when a kinetic investigation was carried out at the different reaction media, temperature and ionic strength $(\mathrm{pH})$. These uncertainties disfavor enzymatic reaction besides the lack of understanding of process. Hence, a standardized method has to be applied to benchmark the enzyme before further use.

Table 2. The kinetic parameters of lipase in the transesterification of oil.

\begin{tabular}{llllll}
\hline Lipase & $V_{\max }(\mathrm{mol} / \mathrm{L} . \mathrm{min})$ & $K_{m, \text { oil }}(\mathrm{mol} / \mathrm{L})$ & $K_{m, a l c}(\mathrm{~mol} / \mathrm{L})$ & $K_{I, \text { alc }}(\mathrm{mol} / \mathrm{L})$ & Ref. \\
\hline Novozym 435 & 0.018 & 397 & 1030 & 1815 & {$[18]$} \\
Novozym 435 & 2.34 & 2.61 & 10.25 & 1.6 & {$[10]$} \\
R. miehei & 0.00022 & 0.0067 & 2.212 & 0.042 & {$[13]$} \\
C. rugosa & 0.170 & 0.137 & 1.081 & 0.826 & {$[19]$} \\
Novozym 435 & 0.000613 & 0.0438 & 0.0008 & 1.0761 & {$[20]$} \\
Burkholderia sp. & 0.61 & 7.93 & 1.01 & 0.24 & {$[21]$} \\
Candida rugosa & 0.0000155 & 0.1083 & 0.1612 & 0.1083 & {$[12]$} \\
B. cepacian & 0.006823 & 0.0837 & 0.159 & 0.00821 & {$[22]$} \\
Burkholderia sp. & 0.0294 & 0.163 & 0.105 & 116.4 & {$[23]$} \\
\hline
\end{tabular}


In the present work, the values of the kinetic, thermal, and operating parameters will be varied to investigate their effects on the reaction performance. The range of parameters used in this study is summarized in Table 3. The simulation was carried out by using Polymath 6.1 software.

Table 3. The range of parameters and constants used.

\begin{tabular}{|c|c|c|}
\hline Parameters or Constants & Values (unit) & Ref. \\
\hline Volume of reactor $(V)$ & $600 \mathrm{~L}$ & \\
\hline Reaction Temperature $(T)$ & $20-60^{\circ} \mathrm{C}$ & \\
\hline Volumetric flow rate $\left(v_{o}\right)$ & $2.5-45 \mathrm{~L} / \mathrm{h}$ & \\
\hline Triglyceride feed concentration $\left(C_{o i l, o}\right)$ & $0.1-1.0 \mathrm{~mol} / \mathrm{L}$ & \\
\hline Methanol feed concentration $\left(C_{m e t, o}\right)$ & $0.5-16 \mathrm{~mol} / \mathrm{L}$ & \\
\hline Initial Enzyme Concentration $\left(E_{o}\right)$ & $1 \mathrm{~g} / \mathrm{L}$ & \\
\hline Gibbs energy of catalysis $\left(\Delta G_{c a t}^{\ddagger}\right)$ & $77 \mathrm{~kJ} / \mathrm{mol}$ & {$[17]$} \\
\hline Gibbs energy of thermal inactivation $\left(\Delta G_{\text {inac }}^{\ddagger}\right)$ & $110-120 \mathrm{~kJ} / \mathrm{mol}$ & {$[17]$} \\
\hline Enthalpy of enzyme transition $\left(\Delta H_{e q}\right)$ & $150 \mathrm{~kJ} / \mathrm{mol}$ & {$[17]$} \\
\hline Enthalpy of enzyme inhibition $\left(\Delta H_{I}\right)$ & $6 \mathrm{~kJ} / \mathrm{mol}$ & {$[24]$} \\
\hline Enthalpy of enzyme-substrate adsorption $\left(\Delta H_{m}\right)$ & $5 \mathrm{~kJ} / \mathrm{mol}$ & {$[24]$} \\
\hline Boltzman's Constant $\left(k_{B}\right)$ & $1.38064852 \times 10^{-23} \mathrm{~m}^{2} . \mathrm{kg} /\left(\mathrm{s}^{2} . \mathrm{K}\right)$ & \\
\hline Planck Constant & $6.62607004 \times 10^{-34} \mathrm{~m}^{2} . \mathrm{kg} / \mathrm{s}$ & \\
\hline Gas constant & $0.008314 \mathrm{~kJ} /(\mathrm{mol} . \mathrm{K})$ & \\
\hline Average molecular weight of lipase & $40,000 \mathrm{~g} / \mathrm{mol}$ & [25] \\
\hline
\end{tabular}

\footnotetext{
* The values are indicative of the parameters and with the same order of magnitude than that reported in the literatures.
}

\section{Results and discussion}

\section{Validation of the model}

The mathematical model of the simulation was initially validated using the data reported by IImi and co-worker [11]. The experimental data were obtained during the transesterification of sunflower oil with methanol in a continuous-stirred-tank reactor. The enzyme was a commercial lipase with a trade name TransZyme A. The estimation of the kinetic parameters is based on the rule of thumbs of enzyme catalysis. The values of the Michaelis constants $\left(K_{m}\right)$ has to be in the same order of magnitude of the substrate concentration. Whereas, the value of inhibition constant $\left(K_{I}\right)$ has to be be less or higher than the concentration of inhibitor presence in the media for highly inhibited and non-inhibited enzyme respectively. The magnitude of the values of Gibbs energy and the change of enthalpies are based on the common enzymes reported in the literature. Figure 2 shows the comparison between the simulated and the actual data for FAME production in a continuous CSTR with a $R^{2}=0.97$. In general, the model is able to predict the actual concentration of FAME produced. The only limitation of the model is unable to accurately predict the lag phase at the early period of the reaction process. Based on the experimental data, it could be observed in few hours that is required by the CSTR before its performance reached a steady-state. The stability of the reaction performance correlates with heat and mass flow rate as well as the homogeneity of the reaction mixture. In the current work, the isothermal and perfect homogeneous mixture was assumed. 


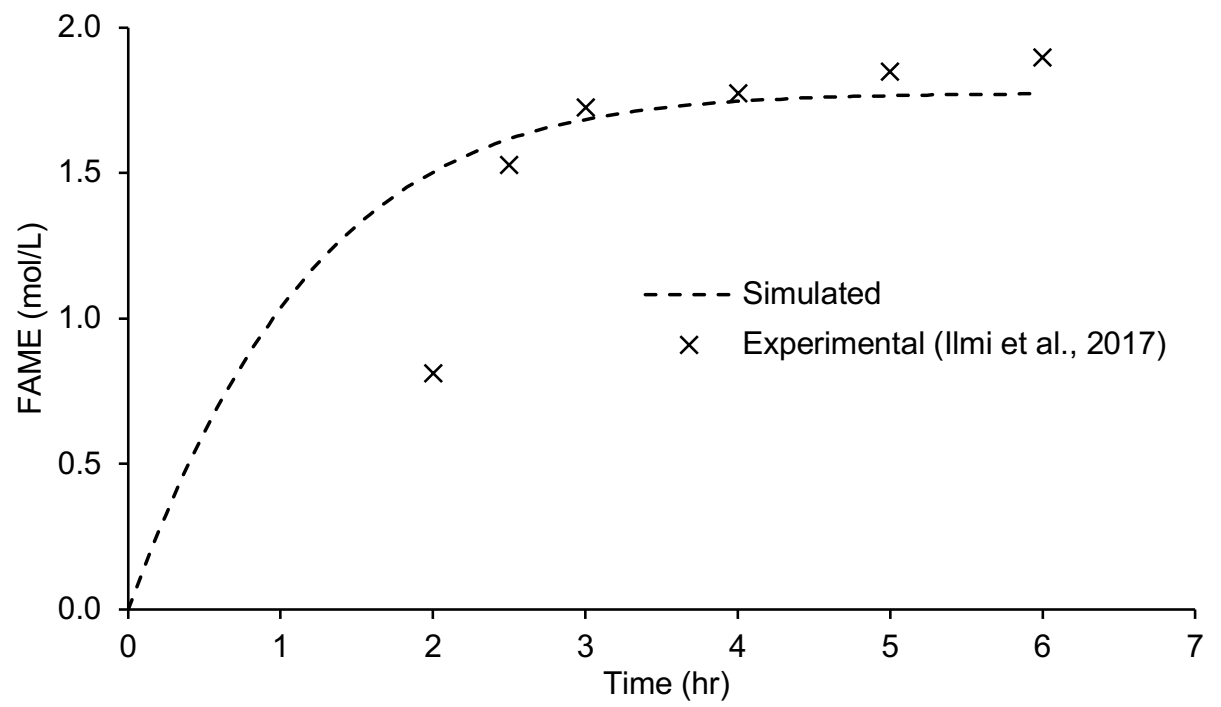

Figure 2. Comparison between simulated data and experimental data by IImi and co-workers [11].

\section{Effect of methanol inhibitor}

The concentration of the substrates is usually manipulated to give the desired rate of reaction and to reach the intended productivity. The maximum concentration of the oil is limited by its density. The average density of plant oils is about $920 \mathrm{~g} / \mathrm{L}$ with an average molecular weight of $840 \mathrm{~g} / \mathrm{mol}$. Hence, its maximum molar density or concentration is about $1.1 \mathrm{~mol} / \mathrm{L}$. Due to considerably high viscosity $(\approx 40$ $\mathrm{cP}$ ) of vegetable oil, a solvent is usually added to ease the operation and this action reduces its concentration. Solvents such as butanol and isooctane could also be added to the reaction mixture. Besides that, an excess amount of methanol also contributes to lower viscosity of the reaction media, on the other hand, it also causes deactivation of the enzyme [26]. Due to the immiscibility of methanol and oil, butanol could be added as a co-solvent to form a homogeneous liquid mixture. The inhibition effect of methanol to the lipase is observed based on the value of the inhibitory constant $\left(K_{I}\right)$. The effect of inhibitor was investigated by increasing the methanol composition at a fix oil content, while the value of $K_{I}$ was remained constant (Table 3). The set value was indicative to the specific lipase. It should be understood that the value varies according to the type of inhibitors, media and the origin of the lipases. Table 4 shows that the conversion of vegetable oil at $K_{I}=100 \mathrm{~mol} / \mathrm{L}$ increases when the methanol ratio was increased from 1:1 to $1: 16$. However, this trend starts to change when the value of $K_{I}$ approaching $0.1 \mathrm{~mol} / \mathrm{L}$ where the conversion starts to decrease at higher methanol contents. Adding an excess of methanol does not necessarily give a better conversion since the lipase is already inhibited. However, it is not too severe as expected if the $K_{I}$ value is significantly large. Notably, the inhibition is not significant when the values of $K_{I}$ significantly larger than the concentration of the inhibitor and vice-versa. The performance of the reaction is very sensitive to the change of inhibitor concentration when the inhibition effect is very significant $\left(K_{I}<1 \mathrm{~mol} / \mathrm{L}\right)$.

Table 4. The effect of inhibition constant values and methanol content on the maximum conversion in the CSTR.

\begin{tabular}{llcccc}
\hline $\begin{array}{l}\text { Oil:Methanol } \\
\text { Molar Ratio }\end{array}$ & $\begin{array}{l}\text { Methanol } \\
(\mathrm{mol} / \mathrm{L})\end{array}$ & $K_{I}=100$ & $K_{I}=10$ & $K_{I}=1$ & $K_{I}=0.1$ \\
\hline $1: 1$ & 0.5 & 0.24 & 0.24 & 0.24 & 0.23 \\
$1: 2$ & 1.0 & 0.44 & 0.44 & 0.43 & 0.29 \\
$1: 4$ & 2.0 & 0.63 & 0.62 & 0.52 & 0.19 \\
$1: 8$ & 4.0 & 0.70 & 0.66 & 0.44 & 0.10 \\
$1: 16$ & 8.0 & 0.72 & 0.64 & 0.32 & 0.06 \\
\hline
\end{tabular}

* The unit of $K_{I}$ is $\mathrm{mol} / \mathrm{L}$ 


\section{Effect of $K_{\mathrm{m}}$ ratio}

The value of $K_{m}$ is very useful to describe the affinity of enzyme and the substrate. For a bi-substrate reaction, the values of $K_{m}$ can be compared to investigate the degree of affinity of the substrates [27]. Later, this would give an impact on the CSTR performance. In the present work, the affinity of oil to enzyme and methanol to the acyl-enzyme complex is represented by $K_{m, o i l}$ and $K_{m, m e t}$, respectively. The reaction proceeds in a two-step mechanism where at first the oil binds to the enzyme to form an acyl-enzyme complex and then followed by the methanol binding to the acyl-enzyme complex before the product formation. Lower value of $K_{m}$ means a better affinity or a formation of the complexes and vice-versa. $K_{m \text {,oil }}$ could be lower or greater than the value of $K_{m, m e t}$ for lipase-catalyzed biodiesel production as these values are unique for a specific lipase. The comparison of the effect of $K_{m}$ ratio on the biodiesel production is shown in Figure 3 . Higher production is obtained when the $K_{m \text {,oil }}<K_{m \text {,met }}$ $\left(K_{m, o i l}=0.15 \mathrm{~mol} / \mathrm{L}\right.$ and $\left.K_{m, m e t}=0.70 \mathrm{~mol} / \mathrm{L}\right)$. Lower production for $K_{m, o i l}>K_{m, m e t}\left(K_{m, o i l}=0.70 \mathrm{~mol} / \mathrm{L}\right.$ and $K_{m, m e t}=0.15 \mathrm{~mol} / \mathrm{L}$ ) indicates that the production of FAME is limited by the formation of the acylenzyme complex. When the value of $K_{m \text {,oil }}$ is large, it reduces the formation of acyl-enzyme for the subsequent step of methanol binding. At $K_{m, o i l}=K_{m, m e t}=0.35 \mathrm{~mol} / \mathrm{L}$, it is usual to expect moderate performance. However, it is recommended to use lipase enzyme with lower $K_{m, o i l}$ and $K_{m, m e t}$ values for the best performance. The reaction is expected to proceed at a faster rate due to a better affinity for both substrates. The output of the reaction (i.e., conversion, yield and concentrations) gives a sluggish response when the $K_{m}$ values are larger, thus take a longer period to reach a steady-state during the continuous operation.

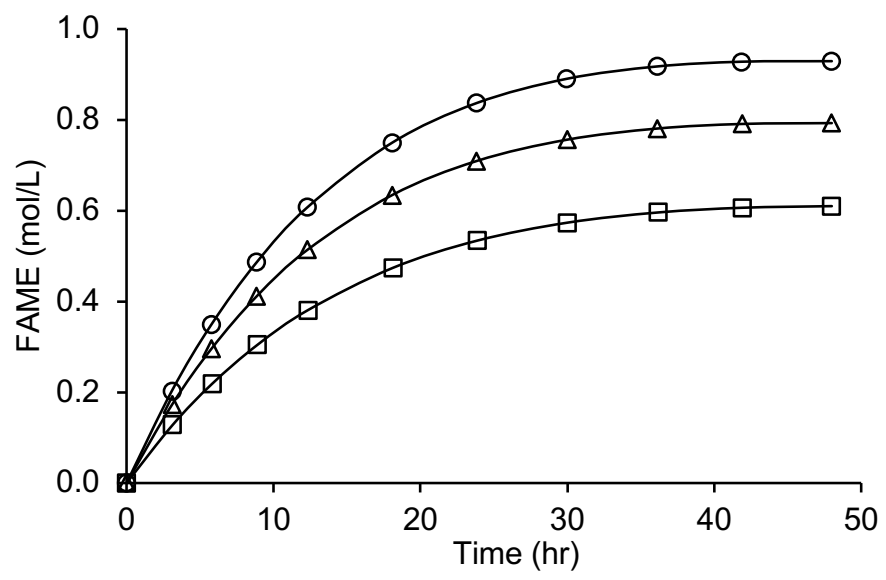

Figure 3. The effect of $K_{m}$ on the productivity of FAME in the CSTR. (०) $K_{m, o i l}<K_{m, m e t}$, (口) $K_{m, o i l}>$ $K_{m, m e t}$ and $(\Delta) K_{m, o i l}=K_{m, m e t}$.

\section{Effect of feed flow rate and concentration}

The performance of reaction in the CSTR is highly dependent on the residence time. The longer the substrate retains in the reactor, the higher the conversion [28]. In contrast with the chemical-catalyzed reaction, there is no side reaction when using a long residence time in the CSTR for an enzymecatalyzed reaction. The residence time in the reactor is prolonged with the slower volumetric flowrate or larger reaction volume $\left(\tau_{\text {Res }}=V / v_{o}\right)$. In this study, the feed volumetric flow rate of oil (Figure 4(a)) and methanol (Figure 4(b)) were varied with a reactor volume of $600 \mathrm{~L}$. Whereas, the feed concentrations of oil and methanol were fixed at 0.5 and $2 \mathrm{~mol} / \mathrm{L}$, respectively. Increasing the feed volumetric flow rate of oil ( 5 to $100 \mathrm{~L} / \mathrm{hr}$ ) has reduced the conversion because of the shorter retention time. The actual period of reaction between the substrate and the enzyme is limited. Hence, most substrates flow out of the reactor without undergoing a transesterification reaction despite a larger molar flow rate. A slower feed volumetric flow rate of oil may give a higher conversion. However, it must not be too low to meet the desired rate of the production as the molar flow rate decreases. For example, the calculated rate of production of FAME at $v_{o, o i l}=100 \mathrm{~L} / \mathrm{hr}$ is about $28.6 \mathrm{~mol} / \mathrm{hr}$ whereas 
only $17.5 \mathrm{~mol} / \mathrm{h}$ at $v_{o, o i l}=5 \mathrm{~L} / \mathrm{hr}$.

Increasing the feed volumetric flow rate of methanol (5 to $100 \mathrm{~L} / \mathrm{hr}$ ) does not significantly change the conversion. It slightly increases by 0.015 at $25 \mathrm{~L} / \mathrm{hr}$ before gradually decline at a faster speed (Figure 4(b)). There is no clear evidence for this behavior which might be due to the present of methanol being the inhibitor. The faster volumetric flow rate would definitely increase the amount of methanol in the CSTR to reach the necessary amount or a so-called optimum reaction. However, methanol causes inhibition hence the lower conversation. In addition, a faster flow rate reduces the residence time which causes a further decrease in the conversion.

It must be noted that the amount of oil and methanol in the CSTR are affected by the inlet concentration and volumetric flow rate. Thus, a similar trend was observed on the conversion when the initial concentration of oil (Figure 4(c)) and methanol (Figure 4(d)) in the feed were increased. An appropriate balance must be estimated in order to keep the ideal molar ratio between the substrates while retaining them for an optimum conversion. Based on the current work, a residence time which above 20 hours is required to achieve oil conversion above $80 \%$. However, an appropriate optimization has to be carried out in a specific reaction condition with the consideration of the operating parameters constraints. In order to improve the conversion of triglycerides, it is suggested that both substrates have to be fed individually with a volumetric flow rate of methanol which is faster than the oil. This setup is able to reduce the residence time for methanol inhibitor while increasing the residence time for the oil.

(a)

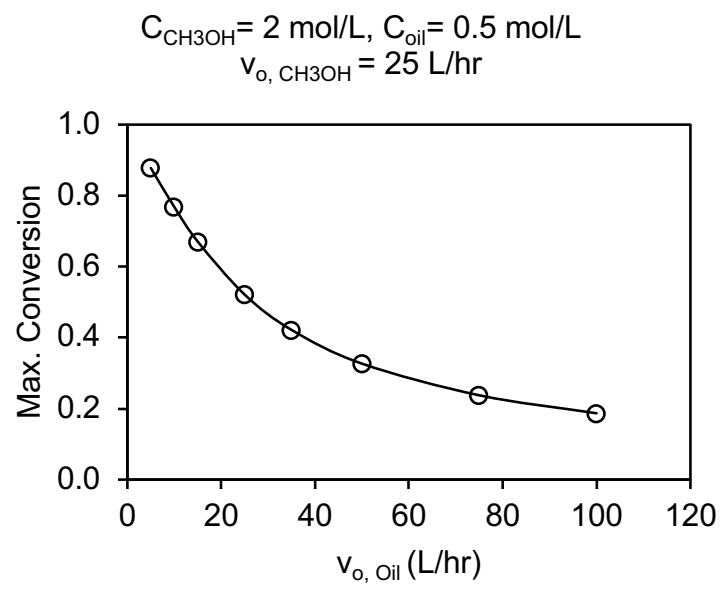

(c)

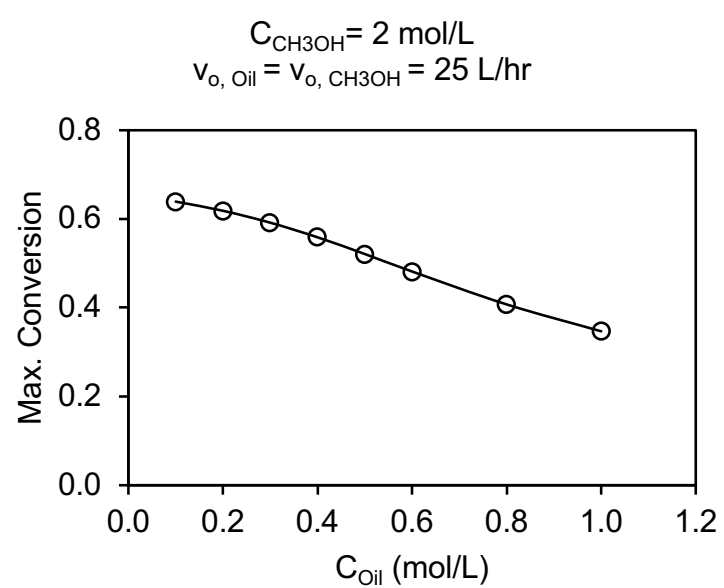

(b)

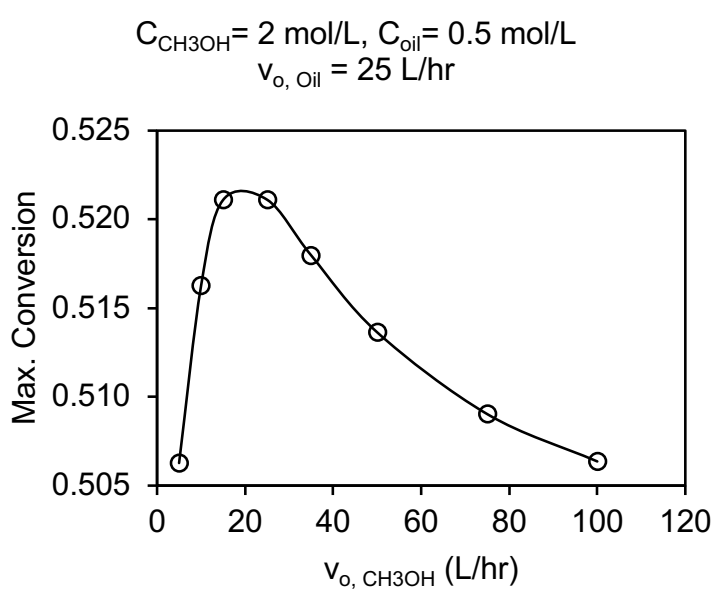

(d)

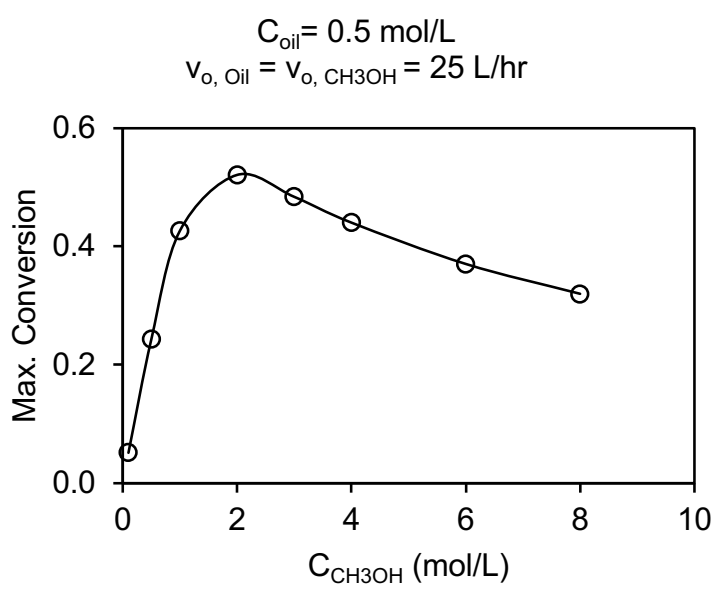

Figure 4. The effect of (a) volumetric flow rate of oil, (b) volumetric flowrate of methanol, (c) oil feed concentration and (d) methanol feed concentration. 


\section{Effect of temperature}

Even though a high temperature rarely leads to a runaway reaction, it does affect the activity of the enzyme. Maintaining optimum temperature is crucial to the lipase-catalyzed reaction as a slight change of temperature within $\pm 5^{\circ} \mathrm{C}$ could significantly change the reaction rate. Moreover, the half-life of the enzyme is also dependent on the operating temperature. Research has shown that an enzyme operated at high temperatures would denature faster [29]. In this work, the effect of temperature (between 20 to $60{ }^{\circ} \mathrm{C}$ ) was investigated. The mathematical model employed considers that the denaturation of lipase occurs at a high temperature and the activation of lipase occurs when the temperature raised to an optimum value [17]. Figure 5 shows that the highest conversion of oil occurs at a temperature of $40{ }^{\circ} \mathrm{C}$. This result agrees with the experimental data reported in the literature of a typical lipase-catalyzed reaction [30,31]. Enzymes usually exhibit activation behavior when the temperature is raised to the optimum level before the denaturation occurs and lose their activities at elevated temperatures. Loss of lipase activities was indicated at a temperature beyond $50{ }^{\circ} \mathrm{C}$ as the conversion of oil is depleted after reaching the highest peak as shown in Figure 5.

\section{Effect of thermal inactivation constant}

A thermal resistant enzyme is an enzyme that can resist high temperature without being denatured. The enzyme can be used for a number of the demanding reaction processes. These types of enzymes can be obtained by isolating from bacterial species growing in a harsh environment [32]. Otherwise, the thermal properties of the enzymes could be also improved via directed mutagenesis or directed evolution [33,34]. The enzyme usually lose their shape and activity with a prolonged use. This phenomenon disfavors an enzyme catalysis for a continuous process. Moreover, the downtime period may increase when the deactivated enzyme is replaced with an active enzyme in the reactor. The life span of the enzyme is indicated by its half-life which means a period taken to halve its initial activity. The half-life of an enzyme depends on its thermal resistance which is represented by the value of thermal inactivation constant.

The impact of the thermally unstable lipase on the biodiesel production in the CSTR was investigated by varying the value of thermal inactivation constant $\left(\Delta G_{\text {inac }}\right)$ as shown in Figure 6 . The value of $\Delta G_{\text {inac }}$ was increased from 110 to $120 \mathrm{~kJ} / \mathrm{mol}$ where the larger value indicates a thermaly stable lipase. The reaction profile was evaluated at $30^{\circ} \mathrm{C}$ and $60^{\circ} \mathrm{C}$ with varying $\Delta G_{\text {inac }}$ values. These temperatures were selected because the enzymatic reaction is usually carried out within this range. The reaction profile at both temperatures shows that the thermal resistance enzyme $\left(\Delta G_{\text {inac }}=120 \mathrm{~kJ} / \mathrm{mol}\right)$ gives a better performance for higher conversions. Overall, the lipase at a higher temperature considerably lose their activities thus, the conversion remains low and the concentration of the substrate remains at the feed concentration. The reaction profile at $30^{\circ} \mathrm{C}$ and $\Delta G_{\text {inac }}=120 \mathrm{~kJ} / \mathrm{mol}$ is the most ideal for a CSTR configuration. The conversion and concentration of the substrates remain constant at most of the 20 days period which indicate a minimal denaturation of the lipase. Regardless of $\Delta G_{\text {inac }}$ values, thermal denaturation of lipase shall take place for a prolonged period of the reaction. The decision to change or add the fresh lipase has to be made at the appropriate time to prevent underperformance of the reaction. The half-life of the enzyme is the best indicator which shows that the other operating parameters remain unchanged. 


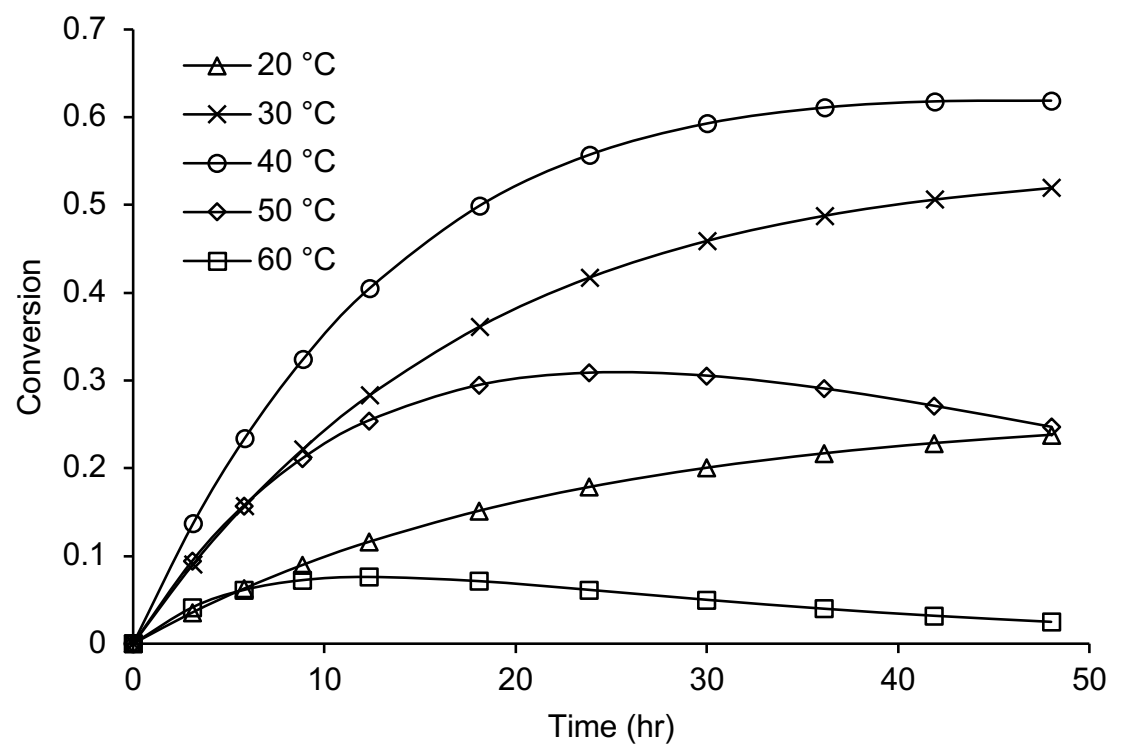

Figure 5. The effect of temperature on the conversion of oil in the CSTR. 
(a)

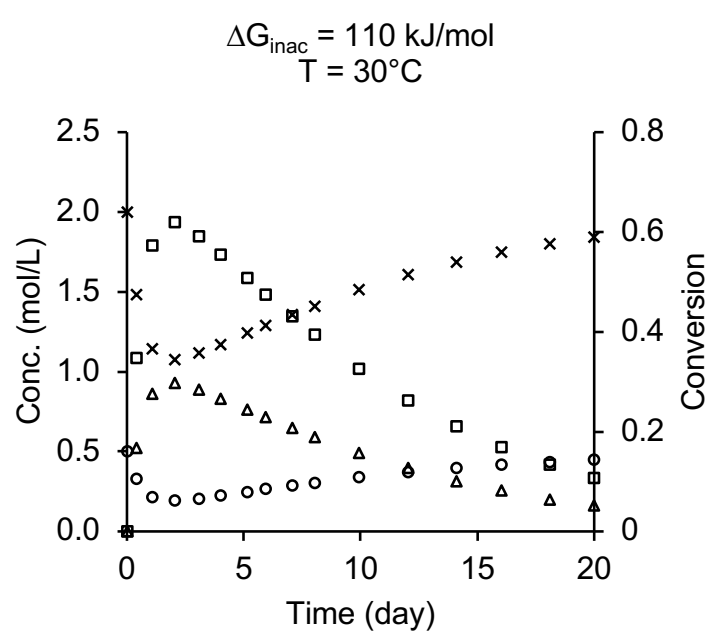

(b)

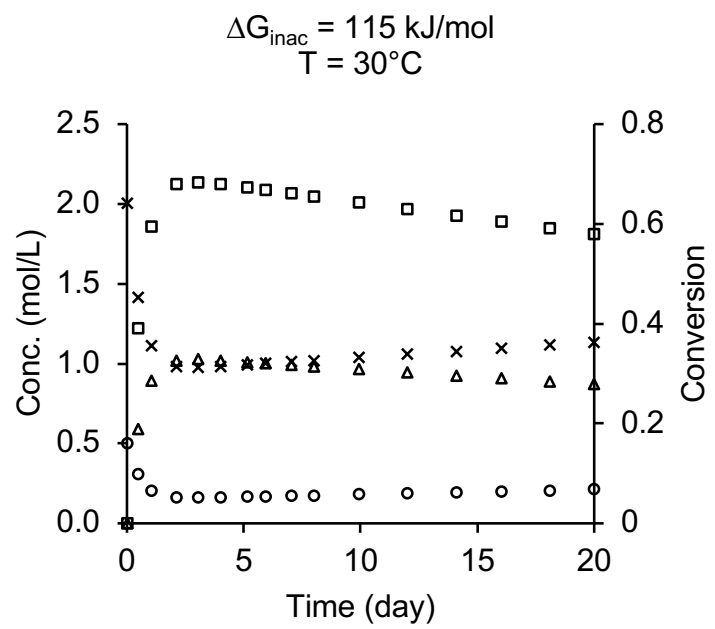

(c)

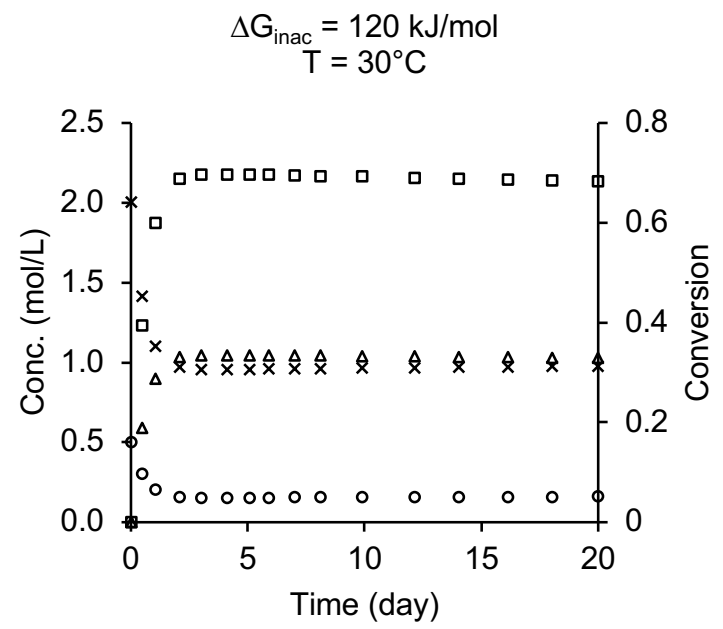

$$
\begin{aligned}
\Delta \mathrm{G}_{\text {inac }} & =110 \mathrm{~kJ} / \mathrm{mol} \\
\mathrm{T} & =60^{\circ} \mathrm{C}
\end{aligned}
$$

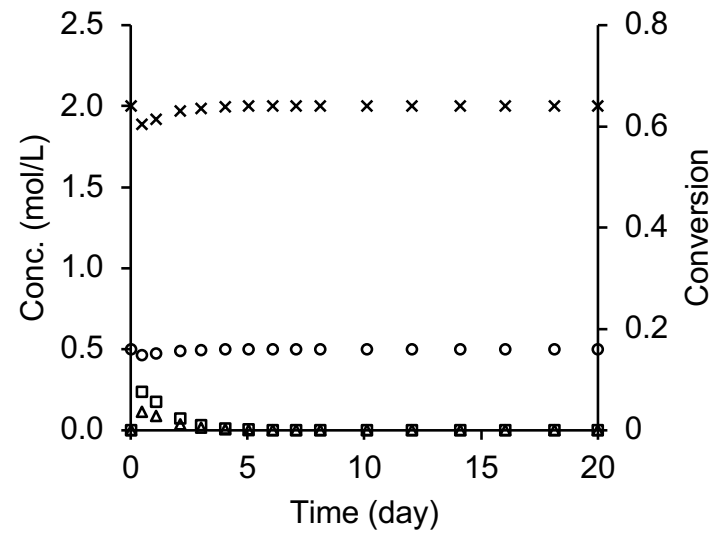

$$
\begin{gathered}
\Delta \mathrm{G}_{\text {inac }}=115 \mathrm{~kJ} / \mathrm{mol} \\
\mathrm{T}=60^{\circ} \mathrm{C}
\end{gathered}
$$

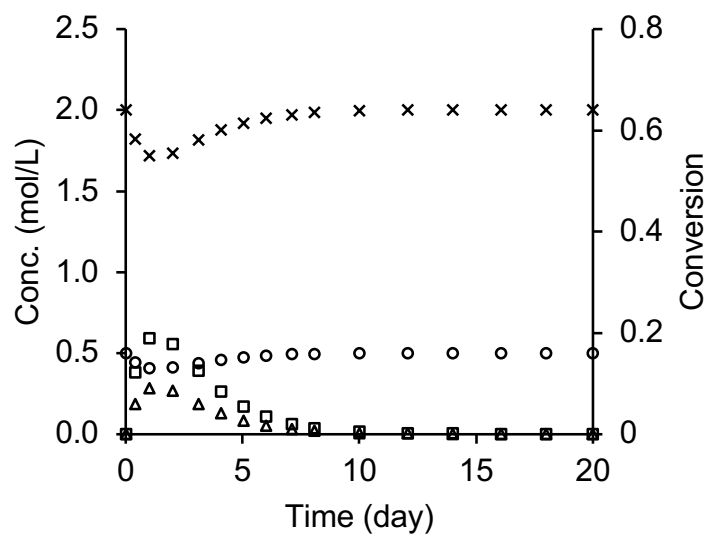

$$
\begin{aligned}
\Delta \mathrm{G}_{\text {inac }} & =120 \mathrm{~kJ} / \mathrm{mol} \\
\mathrm{T} & =60^{\circ} \mathrm{C}
\end{aligned}
$$

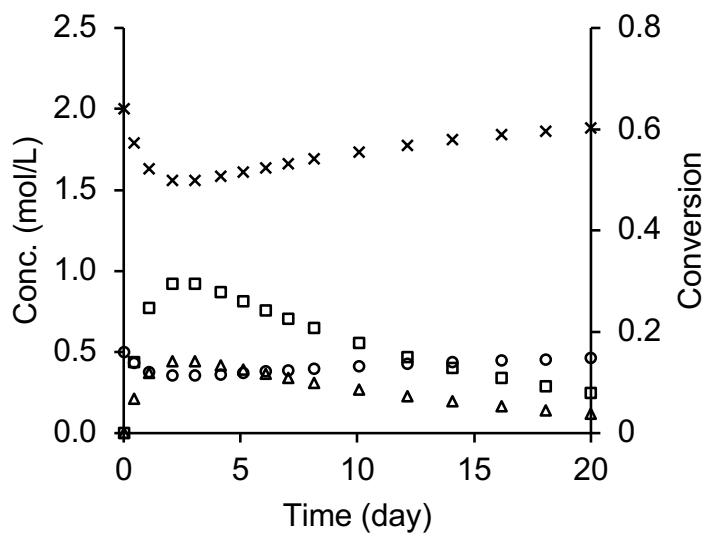

Figure 6. Profile of reactions at temperatures $30^{\circ} \mathrm{C}$ and $60^{\circ} \mathrm{C}$ for lipase with thermal inactivation constants $\left(\Delta G_{\text {inac }}\right)$ of (a) 110 , (b) 115 and (c) $120 \mathrm{~kJ} / \mathrm{mol}$. The legends are; (o) oil, (x) methanol, ( $\Delta$ ) FAME, and (口) conversion. 


\section{Conclusions}

The feasibility and sustainability of the lipase-catalyzed synthesis of FAME in the CSTR was evaluated using mathematical modeling $\left(R^{2}=0.97\right)$ and simulation. The simulation process emphasized the kinetic, thermal, and operating parameters that need to be considered for an enzyme-catalyzed reaction. Lipase with $K_{m}<0.15 \mathrm{~mol} / \mathrm{L}, \Delta G_{\text {inac }}>120 \mathrm{~kJ} / \mathrm{mol}$ and $K_{I, m e t}>100 \mathrm{~mol} / \mathrm{L}$ is an ideal characteristic that gives a fast reaction rate, good thermal stability, and resistance to inhibition. The reaction process is more sustainable if Lipase that meets this criterion is employed. The operating parameters such as temperature and molar flow rate should be manipulated to control the course of the reaction. For a thermally sensitive enzyme, the temperature should remain constant to avoid overdenaturation. The molar flow rate is proportional to the volumetric flow rate and concentration of the feed. The slower volumetric flow rate shall increase the conversion due to longer retention time, however, it must not too low such that to cause lower productivity. Further, the feasibility of the process should be evaluated based on the cost-benefit analysis.

\section{Data availability}

The simulation data and the programming code of this study are available from the corresponding author upon request.

\section{Conflicts of interest}

The authors declares that there is no conflict of interest regarding the publication of this paper.

\section{Funding statement}

A part of this work was supported by Universiti Sains Malaysia through the Short-Term Grant [Ref No. 2019/0566].

\section{Acknowledgments}

The authors would like to acknowledge the Universiti Sains Malaysia for providing the research facilities. The technical support and assistance by the academic and technical staff of the school of chemical engineering are also acknowledged.

\section{References}

[1] M. K. Lam, K. T. Lee and A. R. Mohamed, "Homogeneous, heterogeneous and enzymatic catalysis for transesterification of high free fatty acid oil (waste cooking oil) to biodiesel: A review," Biotechnology Advances, vol. 28, no. 4, pp. 500-518, 2010.

[2] M. Bilal, Y. Zhao, S. Noreen et al., "Modifying bio-catalytic properties of enzymes for efficient biocatalysis: A review from immobilization strategies viewpoint," Biocatalysis and Biotransformation, vol. 37, no. 3, pp. 159-182, 2019.

[3] W. Shuai, R. K. Das, M. Naghdi, S. K. Brar and M. Verma, "A review on the important aspects of lipase immobilization on nanomaterials," Biotechnology and Applied Biochemistry, vol. 64, no. 4, pp. 496-508 2017.

[4] M. Babaki, M. Yousefi, Z. Habibi et al., "Enzymatic production of biodiesel using lipases immobilized on silica nanoparticles as highly reusable biocatalysts: Effect of water, t-butanol and blue silica gel contents," Renewable Energy, vol. 91, no. pp. 196-206, 2016.

[5] F. Al Basir and P. K. Roy, "Study on enzyme inhibition in biodiesel synthesis: Effect of stepwise addition of methanol and removal of glycerol," Energy, Ecology and Environment, vol. 4, no. 2, pp. 75-84, 2019.

[6] F. Zarejousheghani, H.-R. Kariminia and F. Khorasheh, "Kinetic modelling of enzymatic biodiesel production from castor oil: Temperature dependence of the ping pong parameters," The Canadian Journal of Chemical Engineering, vol. 94, no. 3, pp. 512-517, 2016.

[7] V. Makareviciene, M. Gumbyte, V. Skorupskaite and E. Sendzikiene, "Biodiesel fuel production by enzymatic microalgae oil transesterification with ethanol," Journal of Renewable and Sustainable Energy, 
vol. 9, no. 2, pp. 023101, 2017.

[8] H. C. Nguyen, S.-H. Liang, S.-S. Chen et al., "Enzymatic production of biodiesel from insect fat using methyl acetate as an acyl acceptor: Optimization by using response surface methodology," Energy Conversion and Management, vol. 158, no. pp. 168-175, 2018.

[9] M. Lotti, J. Pleiss, F. Valero and P. Ferrer, "Enzymatic production of biodiesel: Strategies to overcome methanol inactivation," Biotechnology Journal, vol. 13, no. 5, pp. 1700155, 2018.

[10] S. F. A. Halim and A. H. Kamaruddin, "Catalytic studies of lipase on fame production from waste cooking palm oil in a tert-butanol system," Process Biochemistry, vol. 43, no. 12, pp. 1436-1439, 2008.

[11] M. IImi, A. Kloekhorst, J. Winkelman et al., "Process intensification of catalytic liquid-liquid solid processes: Continuous biodiesel production using an immobilized lipase in a centrifugal contactor separator," Chemical Engineering Journal, vol. 321, no. pp. 76-85, 2017.

[12] Z. Tan, M. Fang, H. Du et al., "Production of biodiesel catalyzed by candida rugosa lipase at interface of w/o microemulsion system," Journal of the Brazilian Chemical Society, vol. 25, no. pp. 1704-1711, 2014.

[13] H. Veny, M. K. Aroua and N. M. N. Sulaiman, "Kinetic study of lipase catalyzed transesterification of jatropha oil in circulated batch packed bed reactor," Chemical Engineering Journal, vol. 237, no. pp. 123-130, 2014

[14] A. Canet, K. Bonet-Ragel, M. D. Benaiges and F. Valero, "Biodiesel synthesis in a solvent-free system by recombinant rhizopus oryzae: Comparative study between a stirred tank and a packed-bed batch reactor," Biocatalysis and Biotransformation, vol. 35, no. 1, pp. 35-40, 2017.

[15] M. Nordblad, V. T. L. Silva, P. M. Nielsen and J. M. Woodley, "Identification of critical parameters in liquid enzyme-catalyzed biodiesel production," Biotechnology and Bioengineering, vol. 111, no. 12, pp. 24462453,2014

[16] M. Vargas, X. Niehus, L. Casas-Godoy and G. Sandoval, "Lipases as biocatalyst for biodiesel production," Springer New York, New York, NY, pp. 377-390, 2018.

[17] R. M. Daniel and M. J. Danson, "Temperature and the catalytic activity of enzymes: A fresh understanding," FEBS Letters, vol. 587, no. 17, pp. 2738-2743, 2013.

[18] L. Azócar, R. Navia, L. Beroiz, D. Jeison and G. Ciudad, "Enzymatic biodiesel production kinetics using cosolvent and an anhydrous medium: A strategy to improve lipase performance in a semi-continuous reactor," New Biotechnology, vol. 31, no. 5, pp. 422-429, 2014.

[19] A. Habibi, S. Fahim, N. Shirvani and M. Rahimi, "Enzymatic methanolysis reaction of canola oil using capillary channel reactor: Determination of the kinetic constants-involved," Journal of Molecular Catalysis B: Enzymatic, vol. 132, no. pp. 47-53, 2016.

[20] J. M. Encinar, J. F. González, N. Sánchez and S. Nogales-Delgado, "Sunflower oil transesterification with methanol using immobilized lipase enzymes," Bioprocess and Biosystems Engineering, vol. 42, no. 1, pp. 157-166, 2019.

[21] D.-T. Tran and J.-S. Chang, "Kinetics of enzymatic transesterification and thermal deactivation using immobilized burkholderia lipase as catalyst," Bioprocess and Biosystems Engineering, vol. 37, no. 3, pp. 481-491, 2014.

[22] Q. You, X. Yin, Y. Zhao and Y. Zhang, "Biodiesel production from jatropha oil catalyzed by immobilized burkholderia cepacia lipase on modified attapulgite," Bioresource Technology, vol. 148, no. pp. 202-207, 2013.

[23] D.-T. Tran, Y.-J. Lin, C.-L. Chen and J.-S. Chang, "Modeling the methanolysis of triglyceride catalyzed by immobilized lipase in a continuous-flow packed-bed reactor," Applied Energy, vol. 126, no. pp. 151-160, 2014.

[24] K. A. Onysko, H. M. Budman and C. W. Robinson, "Effect of temperature on the inhibition kinetics of phenol biodegradation by pseudomonas putida q5," Biotechnology and Bioengineering, vol. 70, no. 3, pp. 291-299, 2000.

[25] J. Uppenberg, M. T. Hansen, S. Patkar and T. A. Jones, "The sequence, crystal structure determination and refinement of two crystal forms of lipase b from candida antarctica," Structure, vol. 2, no. 4, pp. 293308, 1994.

[26] M. Lotti, J. Pleiss, F. Valero and P. Ferrer, "Effects of methanol on lipases: Molecular, kinetic and process issues in the production of biodiesel," Biotechnology Journal, vol. 10, no. 1, pp. 22-30, 2015.

[27] A. G. Marangoni, "Enzyme kinetics: A modern approach," John Wiley \& Sons, New Jersey, 2003.

[28] H. S. Fogler, "Elements of chemical reaction engineering," Pearson Higher Education \& Professional Group, 2013.

[29] R. M. Daniel, M. Dines and H. H. Petach, "The denaturation and degradation of stable enzymes at high temperatures," Biochemical Journal, vol. 317, no. 1, pp. 1-11, 1996.

[30] Y. X. Li and B. X. Dong, "Optimization of lipase-catalyzed transesterification of cotton seed oil for biodiesel production using response surface methodology," Brazilian Archives of Biology and Technology, vol. 59, no. pp. 2016.

[31] M. H. Xu, I. C. Kuan, F. Y. Deng et al., "Immobilization of lipase from candida rugosa and its application for the synthesis of biodiesel in a two-step process," Asia-Pacific Journal of Chemical Engineering, vol. 11, no. 6, pp. 910-917, 2016.

[32] G. Yasar, U. G. Gulhan, E. Guduk and F. Aktas, "Screening, partial purification and characterization of the hyper-thermophilic lipase produced by a new isolate of bacillus subtilis Ip2," Biocatalysis and Biotransformation, vol. 38, no. 5, pp. 367-375, 2020.

[33] B. S. Heater, W. S. Chan, M. M. Lee and M. K. Chan, "Directed evolution of a genetically encoded immobilized lipase for the efficient production of biodiesel from waste cooking oil," Biotechnology for Biofuels, vol. 12, no. 1, pp. 165, 2019.

[34] Z. Jiang, C. Zhang, M. Tang et al., "Improving the thermostability of rhizopus chinensis lipase through sitedirected mutagenesis based on b-factor analysis," Frontiers in Microbiology, vol. 11, no. pp. 346, 2020. 